\title{
THE IMPACT OF PERSONALITY TRAITS ON PERCEIVED INVESTMENT PERFORMANCE: THE MODERATING ROLE OF SOCIAL INTERACTION
}

\author{
Ninditya Nareswari ${ }^{*}$, Citra Wanodya Rahmani', Nugroho Priyo Negoro' \\ 'Department of Business Management, Faculty of Creative Design and Digital Business, Institut \\ Teknologi Sepuluh Nopember \\ Address :1 Jl Raya ITS Sukolilo, Keputih, Surabaya, Indonesia 60117 \\ *E-mail : ninditya@its.ac.id
}

\begin{abstract}
Each investor has an investment plan to reach their investment objectives. Perceived investment performance was affected by a high level of the psychological aspect. The purpose of this study was to test the effect of the Big Five personality traits on the perception of investment performance. This study also tests the moderating role of social interaction. PLSSEM was used to test the hypotheses. Used individual stock investors in Indonesia, the findings showed that openness personality had a negative effect on perceived investment performance. Otherwise, conscientiousness, extraversion, agreeableness, and neuroticism had a positive impact on perceived investment performance. The results also show that social interaction moderates the relationship between conscientiousness, agreeableness, and perceived investment performance. This result shows that information selection and investment knowledge is important when allocating asset to achieve investment objectives.
\end{abstract}

Keywords: Perceived investment performance, personality traits, social-interaction JEL Classification: G41

Article History :

Received: December 8, 2020; Revised : April 3, 2021; Accepted: April 5, 2021; Available Online : April 26,2021

DOI : $10.20473 /$ imtt.v14i1.23737

\section{INTRODUCTION}

The Indonesian capital market is one of the capital markets that is currently developing. Investment activities in Indonesia's capital market have increased. Based on KSEl data, from 2018 to 2019, total Single Investor Identification (SID) increased by $53.04 \%$ to 2,478,243 SID. (Kustodian Sentral Efek Indonesia, 2020). There are various investment objectives, such as income, security, or growth, to avoid inflation. To get optimal investment returns, investors need to have an investment plan as well as good analytical skills and strategies (Kubilay and Bayrakdaroglu, 2016). Besides successful investment requires control of psychology by $60 \%$ (Tharp, 2008). In the behavioral finance literature, some researchers have modeled the trading behavior of investors based on insights from personality psychology. However, the role of the investor's personality has not been considered more broadly (Akhtar, Thyagaraj and Das, 2018a). By understanding this aspect, investors can manage the potential and investment risks to get good investment performance. Empirical studies show that personality 


\section{Ninditya Nareswari \\ Citra Wanodya Rahmani \\ Nugroho Priyo Negoro}

is an essential basis that builds investor's attitudes, behavior, and preferences (Phung and Khuong, 2016). This study will explain how personality and social interactions affect the perceived investment performance. This study also formulated theoretical and managerial implications applied by individual investors, capital market regulators, and financial advisors.

There are many previous studies related to the role of personality traits on investment performance. The study by (Akhtar, Thyagaraj and Das, 2018a)shows that individuals who have high conscientiousness, agreeableness, and neurotic tend to be satisfied with their investment performance. Through regression analysis, individuals with high extraversion also offer the same satisfaction with investment performance. Phung and Khuong, (2016)also showed that extraversion, openness, and agreeableness directly affect investment performance. Extraversion and openness can influence investment performance through positive moods, whereas agreeableness and neuroticism influence negative attitudes. Also, investors with neurotic personalities choose not to invest in stocks. This research shows that individual investors should be in a good mood when investing in stocks. Chen et al., (2019)showed that Investor personality affects investment performance in both the long and short term. Investors with openness, conscientiousness, and extraversion tend to have better investment performance than investors with neuroticism.

In line with the previous study, this study examines the role of the big five personality traits on investment performance. Still, this study develops the model by adding social interaction as the moderation variable. Phung and Khuong, (2016) explain that investors in Asia tend to be trapped by behavioral bias in making investment decisions, so retail investors in Indonesia are chosen as the sample of this study.

\section{LITERATURE REVIEW AND HYPOTHESES}

\section{Personality}

Personality is a relatively permanent character pattern and a unique character that provides both consistency and individuality to individual behavior (Sina, 2014). According to Dole and Schroeder, (2001) personality is a combination of emotional, cognitive, and motivational characteristics that differentiate and influence how individuals respond to their environment and make decisions. Personality theory is divided into several models. Researchers generally use the Big Five model to measure individual personalities (Akhtar, Thyagaraj and Das, 2018b). Barrick and Mount, (1991) revealed that the Big Five model is considered highly relevant for measuring individual personality compare to other personality models. That is because the Big Five model has a high level of acceptance in widely applied research (Barrick and Mount, 1991). Costa and McCrae, (1992) classified the Big Five personality 
characteristics into openness, conscientiousness, extraversion, agreeableness, and neuroticism.

\section{Social Interaction}

Ellison and Fudenberg, (1995) describe social interaction as a way to gather information and analyze others' emotional reactions so that they can form an opinion. Meanwhile, according to Chaplin, (2012), social interaction is a social relationship between individuals to influence each other. From these definitions, it can be concluded that social interaction is the social relationship of individuals in obtaining information so that an opinion is formed and can change and influence the individual.

Social interaction has an important role when it comes to investment activities. One of the impacts of social interaction is the exchange of information that allows a person to make investment decisions (Eugene and Yuan, 2012). The capital market can be viewed as a system of social interaction (Hirschey, M. Nofsinger, 2008). In general, individual investors can influence each other and follow and respond to investment decisions from a group of people (Javed, Bagh and Razzaq, 2017). Investors tend to rely on social interactions in making investment decisions even though the information obtained through social interactions does not necessarily help investors improve the quality of their investments (Javed, Bagh and Razzaq, 2017)

Investors with an open personality are curious, develop new ideas and points of view (Costa and McCrae, 1992). However, in practice, investors' various information tends to make investment decisions irrational, and the investment performance obtained is not optimal (Akhtar, Thyagaraj and Das, 2018a). Chen et al., (2019)showed that openness investors realize that changing capital market conditions do not always provide good performance. Therefore, social interaction will support them to collect the related information and advice from professionals or other investors who can improve their investment performance (Tauni et al., 2017).

Investors with a conscientious personality are more goal-oriented and very active in making decisions until their goals are achieved (Costa and McCrae, 1992). In general, they tend to have better long-term investment performance (Chen, Ho and Liu, 2019) and expect high investment performance (Akhtar, Thyagaraj and Das, 2018b). Heinstrom, (2010)states that investors with conscientious personalities consistently try to get reliable information to get high investment performance. Social interaction will help them get credible information and make investment decisions based on their risk preferences (Tauni et al., 2017) 


\section{Ninditya Nareswari \\ Citra Wanodya Rahmani \\ Nugroho Priyo Negoro}

Investors with extraversion personalities are optimistic, socialize, and ambitious (Heinstrom, 2010). They know the best decisions for their portfolios. They will not hesitate to reject or make changes in their investment plans (Akhtar, Thyagaraj and Das, 2018a) and get used to evaluating their investment performance (Tauni et al., 2017). Besides, these investors tend to cultivate positive energy and have high self-confidence when the perceived investment performance does not match the expected performance (Tauni et al., 2017). In that case, extraversion investors will design a better and more promising investment strategy to get better investment performance in the future (Durand, Newby and Sanghani, 2008). Besides, social interaction also helps the investor to compare and evaluate their portfolio (Tauni et al., 2017).

Investors with an agreeableness personality are forgiving, soft-hearted, kind, and wellreceived by their peers (Martins, 2002). Also, they trust other people without any judgment of information and are ready to accept all forms of misinformation (Heinstrom, 2010). However, Tauni et al., (2017)revealed that investors with this personality would first consider the best method to apply to their portfolios. Besides, Chen et al. (2019) show that investor with agreeableness personality tends to produce good long-term investment performance. Social interaction for investors with agreeableness personality can cause instability in their portfolios. Because they are rarely curious and tend to be non-judgmental, sometimes being naive (Costa and McCrae, 1992), and lack expertise and opinion in evaluating investments (Ivković and Weisbenner, 2007).

Investors with neuroticism personality tend to feel anxious and insecure about fluctuating stock market conditions that increase nervousness and fear of investing (Tauni et al., 2017). Akhtar et al.,(2018b) also stated that neurotic investors are sensitive to their external environment and often overreact to ordinary situations. However, Krohne,et al, (2000) revealed that high neuroticism encourages individuals to assure themselves of important decision-making aspects. Tauni et al., (2017) explain that social interaction influences investment decision-making by understanding the stock market situation to reduce the fear, and nervousness neuroticism investors have.

\section{Perceived Investment Performance}

Perceived investment performance is a self-evaluation of investment returns based on perceived investment performance (Javed, Bagh and Razzaq, 2017). In this study, perceived investment performance will be measured by investor satisfaction on investment performance based on the market base rate and compared with inflation risk (Sato, Miyazaki and Mawaribuchi, 2011). A Study by Akhtar et al., (2018a)and Phung and Khuong, (2016)states that investor behavior plays an essential role in perceptions of investment 
performance. To achieve a higher return, investors with low ability will reduce the intensity of transactions. Certain psychological factors can influence investors in making investment decisions and influence investors' assessment of their investment performance (Abdin et al., 2017).

According to the previous literature, The following hypothesis are proposed.

$H_{1 a}$ : Openness has a negative effect on perceived investment performance

$H_{1 b}$ : Conscientiousness has a positive effect on perceived investment performance

$H_{1 c}$ : Extraversion has a positive effect on perceived investment performance

$H_{1 d:}$ Agreeableness have a positive effect on perceived investment performance

$\mathrm{H}_{1 \mathrm{e}}$ : Neuroticism have a positive effect on perceived investment performance

$\mathrm{H}_{2 \mathrm{a}}$ : Social interaction weakens a negative relationship between openness and perceived investment performance

$\mathrm{H}_{2 b}$ : Social interaction strengthen a positive relationship between conscientiousness and perceived investment performance

$\mathrm{H}_{2 \mathrm{c}}$ : Social interaction strengthen a positive relationship between extraversion and perceived investment performance

$\mathrm{H}_{2 \mathrm{~d}}$ : Social interaction weakens a positive relationship between agreeableness and perceived investment performance

$\mathrm{H}_{2 \mathrm{e}}$ : Social interaction strengthen a positive relationship between neuroticism and perceived investment performance

\section{RESEARCH METHODS}

This study used a quantitative conclusive-descriptive approach. The survey was conducted among investors in Indonesia, from November to December 2019. The questionnaires were distributed to them using email, social media, and instant messenger. The criteria for respondents in this study are individual stock investors in the Indonesian capital market with at least one year of active investment experience. Using Slovin Equation, 445 samples were collected. This study used the Partial Least Square- Structural Equation Model (PLS-SEM) as a method. PLS-SEM is a suitable method when the main objective is to examine a relationship, direction, and strength of variables. Data collection in this study was conducted by using a questionnaire instrument. The pilot test will be conducted on 30 prospective respondents to improve the quality of the questionnaire by identifying and eliminating potential problems and obtaining the reliability and validity of the questionnaire.

The outer model measurement is used to assess the reliability and validity of the model. The measurement of the internal consistency value uses Cronbach's alpha and composite 


\section{Ninditya Nareswari \\ Citra Wanodya Rahmani \\ Nugroho Priyo Negoro}

reliability. Then, convergent validity is computed by Average Variance Extracte d (AVE). Besides, inner model measurements were conducted to evaluate the suitability of research hypotheses and to differentiate between relevant causal hypotheses and those that do not support empirical evidence (Hair et al., 2017). Q squared are used to compute predictive relevance, and path coefficients are used to measure the hypothesized relationship to the construct.

Table 1.

Operational definitions and measurement of variables

\begin{tabular}{|c|c|c|c|}
\hline Variables & Definition & Item & References \\
\hline $\begin{array}{l}\text { Personality } \\
\text { Traits }\end{array}$ & $\begin{array}{l}\text { A relatively } \\
\text { permanent } \\
\text { character pattern } \\
\text { and a unique } \\
\text { character that } \\
\text { provides both } \\
\text { consistency and } \\
\text { individuality to } \\
\text { individual } \\
\text { behavior (Sina, } \\
\text { 2014) }\end{array}$ & $\begin{array}{l}\text { Openness } \\
\text { O1. I have mixed ideas } \\
\text { O2. I have high intellectual curiosity } \\
\text { O3. I am interested in new things that } \\
\text { I find } \\
\text { O4. I like new theories or abstract } \\
\text { ideas } \\
\text { O5. I am interested in exploring the } \\
\text { environment around me } \\
\text { O6. I like fun activities } \\
\text { Conscientiousness } \\
\text { C1. I'm pretty good at getting work } \\
\text { done on time } \\
\text { C2. Sometimes I am as reliable as I } \\
\text { can be } \\
\text { C3. I keep my belongings neat and } \\
\text { clean } \\
\text { C4. I wasted a lot of time before stop } \\
\text { working } \\
\text { C5. I can give a good solution } \\
\text { C6. I paid attention to something in } \\
\text { detail } \\
\text { Extraversion } \\
\text { E1. I really like socializing with other } \\
\text { people } \\
\text { E2. I often feel as if I have a lot of } \\
\text { energy } \\
\text { E3. I am a cheerful and passionate } \\
\text { person } \\
\text { E4. I am an active person } \\
\text { E5. I tend to make friends with other } \\
\text { people easily } \\
\text { E6. I'm less shy and talkative } \\
\text { Agreeableness } \\
\text { A1. I try to be a wise person when } \\
\text { considering decisions }\end{array}$ & $\begin{array}{l}\text { Akhtar et al., } \\
\text { (2018b), Durand } \\
\text { et al., (2008), } \\
\text { Novianty and } \\
\text { Widyaastuti, } \\
\text { (2019) Tauni } \\
\text { et al (2017) }\end{array}$ \\
\hline
\end{tabular}




\begin{tabular}{|c|c|c|c|}
\hline & & $\begin{array}{l}\text { A2. I rarely get into arguments with } \\
\text { my family and colleagues } \\
\text { A3. Some people think I am not a } \\
\text { selfish person } \\
\text { A4. I am assertive and confident } \\
\text { person } \\
\text { A5. I tend to be able to control my } \\
\text { anger and emotions } \\
\text { A6. I am sometimes not interested in } \\
\text { other people's problems } \\
\text { Neuroticism } \\
\text { N1. Under tremendous pressure and } \\
\text { burden, sometimes I want to go and } \\
\text { vent my feelings } \\
\text { N2. Sometimes I feel myself worthless } \\
\text { N3. When things go wrong, } \\
\text { sometimes I get discouraged and } \\
\text { want to give up } \\
\text { N4. Sometimes I feel inferior when } \\
\text { compared to other people } \\
\text { N5. I tend to worry about many } \\
\text { things } \\
\text { N6. I sometimes feel tense and } \\
\text { anxious }\end{array}$ & \\
\hline $\begin{array}{l}\text { Social } \\
\text { Interaction }\end{array}$ & $\begin{array}{l}\text { Individual social } \\
\text { relations in } \\
\text { obtaining } \\
\text { information to } \\
\text { form an opinion } \\
\text { that can change } \\
\text { and influence the } \\
\text { individual. } \\
\text { (Bonner, 1953; } \\
\text { Chaplin, 2011; } \\
\text { Ellison and } \\
\text { Fudenberg, 1995; } \\
\text { Young, 1956) }\end{array}$ & $\begin{array}{l}\text { Social Interaction } \\
\text { S1. People closest to me (eg parents, } \\
\text { spouse, children, etc.) think that I } \\
\text { should make a financial investment } \\
\text { in the stock market } \\
\text { S2. My environment encourages me } \\
\text { to invest in the stock market } \\
\text { S3. I invested in the stock market } \\
\text { because my friends did too } \\
\text { S4. I sometimes buy a stock if } \\
\text { someone is promoting it } \\
\text { S5. I hope to invest or make } \\
\text { transactions in the stock market in } \\
\text { the near future (e.g next month) } \\
\text { S6. I am looking for information } \\
\text { about the evaluation of share prices } \\
\text { and matters relating to their } \\
\text { performance }\end{array}$ & $\begin{array}{l}\text { Akhtar et al., } \\
(2018 b)\end{array}$ \\
\hline $\begin{array}{l}\text { Perceived } \\
\text { Investment } \\
\text { Performance }\end{array}$ & $\begin{array}{l}\text { Self-analysis of } \\
\text { investment } \\
\text { according to the } \\
\text { investment } \\
\text { performance } \\
\text { (Javed et al, 2017) }\end{array}$ & $\begin{array}{l}\text { Perceived Investment Performance } \\
\text { P1. The rate of return on my stock } \\
\text { investment met my expectations. } \\
\text { P2. The rate of return on my stock } \\
\text { investment is more than the market } \\
\text { average rate of return. } \\
\text { P3. I am satisfied with my investment } \\
\text { decisions (including selling, buying, } \\
\text { selecting, and deciding the volume } \\
\text { of shares). } \\
\text { P4. My investment performance and } \\
\text { returns beat the risk of inflation. } \\
\text { P5. I am willing to wait for a more } \\
\text { favorable return in the future. }\end{array}$ & $\begin{array}{l}\text { Akhtar et al., } \\
\text { (2018b), Abdin } \\
\text { etal., (2017) } \\
\text { Chen et al., } \\
\text { (2019) }\end{array}$ \\
\hline
\end{tabular}




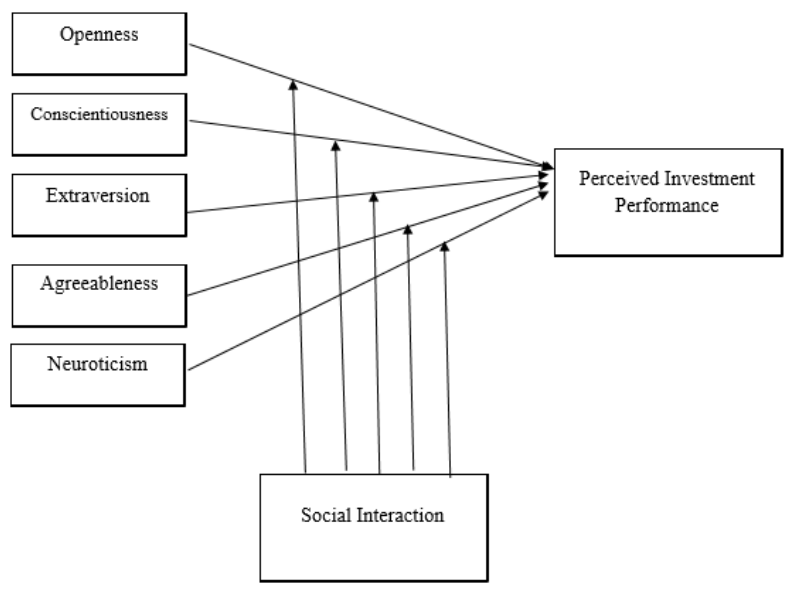

Figure 1.

The Research Model

\section{RESULTS AND DISCUSSION}

Table 2 shows the demographic characteristics of the respondents. As shown in table 1, most of respondents were male (72,13\%), 20-40 years old $(68,31 \%)$, have portfolio less than $50.000 .0000(54,38 \%)$, and $1-3$ year of experience in investment $(62,70 \%)$. Table 3 shows that all AVEs were above 0.5, therefore the model is acceptable. In addition, all alphas and composite reliability values were above 0.7 , which indicated that each construct's reliability was reasonably satisfied (Table 2). Predictive relevance is an indicator of predictive power or the predictive relevance of out-of-sample models (Hair et al., 2014). The $Q$ Square calculation shows that the magnitude of the research data explained by the structural model is $54.0 \%$. The structural research model can describe $54.0 \%$ of the actual conditions, and there are $46.0 \%$ of factors outside the research that needs to be explored again. The value of $Q$ square is above 0 , so the model able to make relevant predictions.

Table 2.

Demographic Characteristics of Respondents

\begin{tabular}{|c|c|c|c|}
\hline $\begin{array}{l}\text { Demographic } \\
\text { characteristics }\end{array}$ & Categories & $\begin{array}{l}\text { Frequency } \\
\mathrm{N}=445\end{array}$ & $\begin{array}{c}\text { Percentage } \\
(\%)\end{array}$ \\
\hline \multirow[t]{2}{*}{ Gender } & Male & 321 & 72.13 \\
\hline & Female & 124 & 27.87 \\
\hline \multirow[t]{4}{*}{ Age } & $<20$ & 25 & 5.62 \\
\hline & $20-40$ & 304 & 68.31 \\
\hline & $41-60$ & 111 & 24.94 \\
\hline & $>60$ & 5 & 1.12 \\
\hline \multirow[t]{4}{*}{ Valve of Portfolio } & $<$ IDR 50.000.000 & 242 & 54.38 \\
\hline & IDR 50.000.000-250.000000 & 92 & 20.67 \\
\hline & IDR 250.000.001-500.000.000 & 53 & 11.91 \\
\hline & $>500.000 .000$ & 58 & 13.03 \\
\hline
\end{tabular}




\begin{tabular}{lccc}
\hline $\begin{array}{l}\text { Year of Experience in } \\
\text { investment }\end{array}$ & $1-3$ years & 279 & 62.70 \\
& $4-6$ years & 87 & 19.55 \\
& $7-9$ years & 38 & 8.54 \\
& $>9$ years & 41 & 9.21 \\
\hline
\end{tabular}

Table 3.

Convergent Validity and Reliability Test

\begin{tabular}{lcccc}
\hline \multicolumn{1}{c}{ Latent variable } & $\begin{array}{c}\text { No of } \\
\text { items }\end{array}$ & AVE & CR & Cronbach's Alpha \\
\hline Openness & 6 & 0.615 & 0.905 & 0.874 \\
Conscientiousness & 6 & 0.718 & 0.938 & 0.921 \\
Extraversion & 6 & 0.647 & 0.917 & 0.891 \\
Agreeableness & 6 & 0.686 & 0.929 & 0.908 \\
Neuroticism & 6 & 0.565 & 0.886 & 0.846 \\
Social Interaction & 6 & 0.532 & 0.872 & 0.831 \\
Perceived Investment & 5 & 0.579 & 0.873 & 0.818 \\
performance & & & & \\
\hline
\end{tabular}

The result of hypothesis testing were showed in table 4. Based on the table, the relationship between openness and perceptions of investment performance and the role of moderation in the relationship between agreeableness and perceived investment performance has a significant negative path coefficient value. This shows that there is a negative relationship between the variables of openness and perceived investment performance as well as social interaction which weakens the relationship between agreeableness and perceived investment performance. The significance level used in this research hypothesis is 0.05 . So the relationship between variables are significant if the $p$-value $\leq 0.05$ and the t-statistic value $\geq 1.96$. The empirical results show that seven hypotheses are supported

Table 4

Hypothesis Testing

\begin{tabular}{|c|c|c|c|c|}
\hline Hypothesis & $\begin{array}{c}\text { Path } \\
\text { Coeffici } \\
\text { ent }\end{array}$ & $\begin{array}{c}t- \\
\text { statisti } \\
\text { cs }\end{array}$ & $\begin{array}{c}\text { p- } \\
\text { values }\end{array}$ & Result \\
\hline $\begin{array}{l}\text { Openness } \rightarrow \text { Perceived Investment } \\
\text { performance }\end{array}$ & -0.124 & 2.909 & 0.004 & Accepted \\
\hline $\begin{array}{l}\text { Conscientiousness } \rightarrow \text { Perceived } \\
\text { Investment performance }\end{array}$ & 0.109 & 2.142 & 0.033 & Accepted \\
\hline $\begin{array}{l}\text { Extraversion } \rightarrow \text { Perceived Investment } \\
\text { performance }\end{array}$ & 0.119 & 2.027 & 0.043 & Accepted \\
\hline $\begin{array}{l}\text { Agreeableness } \rightarrow \text { Perceived Investment } \\
\text { performance }\end{array}$ & 0.182 & 3.973 & 0.000 & Accepted \\
\hline $\begin{array}{l}\text { Neuroticism } \rightarrow \text { Perceived Investment } \\
\text { performance }\end{array}$ & 0.119 & 2.967 & 0.003 & Accepted \\
\hline $\begin{array}{l}\text { Openness * Social Interaction } \rightarrow \\
\text { Perceived Investment performance }\end{array}$ & 0.005 & 0.123 & 0.902 & Rejected \\
\hline Conscientiousness * Social Interaction $\rightarrow$ & 0.154 & 3.426 & 0.001 & Accepted \\
\hline
\end{tabular}




\section{Ninditya Nareswari \\ Citra Wanodya Rahmani \\ Nugroho Priyo Negoro}

Perceived Investment performance

Extraversion * Social Interaction $\rightarrow$

Perceived Investment performance

Agreeableness * Social Interaction $\rightarrow$

$-0.060$

1.287

0.199

Rejected

Perceived Investment performance

$\begin{array}{llll}-0.119 & 2.464 & 0.014 & \text { Accepted }\end{array}$

Neuroticism * Social Interaction $\rightarrow$

$-0.058$

1.291

0.165

Rejected

Perceived Investment performance

To achieve investment goals, investors should consider many aspects, not only the strategies but also the psychological aspect. The psychological aspect of investors can influence the decision making of investment. This study aims to test the role of personality traits on perceived investment performance. This study also tests the moderation role of social interaction in the relationship between personality traits and perceived investment performance. Based on the result, Hypothesis la is accepted. This result shows that individual investors who have low openness personalities get a return that can fulfill their expectations. In line with Akhtar et al., (2018a), openness personality has a high curiosity and likes to learn new things. This attitude can influence investors' decisions to try new investing methods or change their investment plans, resulting in sub-optimal returns and not reaching their investment objectives (Tauni et al., 2017). Conversely, investors with low openness personalities tend to focus on their investment plans to achieve maximum returns (Akhtar, Thyagaraj and Das, 2018b)

The result also showed that hypothesis $1 \mathrm{~b}$ is accepted. This result shows that individual investors who have high conscientiousness get a return that can fulfill their expectations. Durand et al., (2008) explain that a key to the success of an investment is consistency. Investors who have high conscientiousness will consistent in their investment plan. Therefore, investors with a conscientious personality can get their portfolio investment performance as they expected.

Hypothesis $1 c$ is accepted. This result shows that individual investors who have a strong extraversion personality get returns that can fulfill their expectations. Investors who have a strong extraversion personality can decide their portfolio's best decision, and they will not doubt to reject or change their investment plan. They are confident in making a strategy and feel optimistic about their portfolio performance in the future (Durand, Newby and Sanghani, 2008).

Hypothesis 1d is accepted. This result shows that individual investors who have high extraversion personalities get returns that can fulfill their expectations. Agreeableness is a personality that refers to a cooperative individual. Investors with an agreeableness personality tend to follow the suggestions given by their colleagues, financial advisors, and 
mentors to get high investment returns (Durand, Newby and Sanghani, 2008). On the other hand, investors with this personality will consider the best suggestion carefully, then apply it to their portfolios (Tauni et al., 2017).

Hypothesis le is accepted. This result shows that individual investors who have high neuroticism get a return that can fulfill their expectations. Investors who have high neuroticism tend to feel worried, jealousy, and fear. Moreover, these investors are slow in responding to stock market conditions and do not have a reasonable investment strategy. On the other hand, high neuroticism investors have a strong commitment to investing in the future (Chen, Ho and Liu, 2019). Therefore, high neuroticism investors tend to choose safe stocks to avoid the risk or negative consequences that might be received (Durand, Newby and Sanghani, 2008). Besides, high neuroticism investors tend to follow big players in the stock market and ask financial advisors for help in making investment decisions (Tauni et al., 2017). They will also consider various things that are considered important in making decisions in the stock market. These are considered to be able to maintain perceived investment performance and reach the expectation.

Hypothesis $2 b$ is accepted. This result indicates the relationship between conscientiousness and perception of investment performance is moderated by social interaction. Social interactions between investors and other investors can influence their investment activities, including making investment decisions. Investors with a conscientious personality tend to be careful in every investment decision and are more oriented toward investment goals (Akhtar, Thyagaraj and Das, 2018a). However, under the influence of social interactions, investors with a conscientious personality will consider using the information obtained if only it matches their investment plans (Tauni et al., 2017). So they improve investment performance to more optimal and provides high returns.

Hypothesis $2 d$ is accepted. This result indicates the relationship between agreeableness and perception of investment performance is moderated by social interaction. Because investors are easy to agree with, they tend to follow the suggestions given by colleagues, financial advisors, and mentors (Durand, Newby and Sanghani, 2008). Acquiring too much information encourages investors to make irrational decisions so that this can result in investment performance and perceived returns that are not optimal (Chen, Ho and Liu, 2019).

\section{CONCLUSION}

The main goal of this study is to examine the role of personality traits and social interaction on investment performance. Used PLS SEM to examine the hypotheses, the results indicate that personality affects on perceived investment performance. Besides, social interaction has a 


\section{Ninditya Nareswari \\ Citra Wanodya Rahmani \\ Nugroho Priyo Negoro}

role as a moderating variable. The results of this study are expected to contribute to the knowledge of personality traits and social interactions and study perceived investment performance by individual investors.

Previous studies also support the results of this study. Retail investors consider their decisions based on their characteristics and psychological bias (Durand et al., 2008; Patterson and Daigler, 2014; Akhtar et al., 2018a; Tauni et al., 2020). Investors also tend to collect a variety of information and take shortcuts to facilitate decision-making. However, most investors only focus on the method without realizing the psychological aspect and understanding it. Successful investment requires mature psychology. Therefore, the capital market regulator needs to provide education about the psychology of investors.

Individual investors are easy to be influenced by social interaction. So it is possible to affect their investment decisions. Besides, the allocation of assets by individual investors generally relies on external factors, such as advice from family and colleagues, information, etc. Asset allocation and portfolio diversification are essential to achieve investment goals, both in the long and short term. Misallocation of assets can hinder an investor's investment objectives; therefore, individual investors need protection against social interactions to avoid investment losses. Besides, investors need to take quick and rational action when they get new information about companies, the stock market, or economic developments. So the selection of information process obtained from social interactions must be strictly selected as well as possible. Investors should not immediately make decisions without the right information. Besides, financial literacy is important to make investors choose the right investment allocation based on their risk preferences (Mahdzan, Mohd-Any and Chan, 2017).

For financial advisors, information about the stock market must be presented clearly and simply so it can be received by investors properly. Financial advisors can also help investors by asking for specific investor preferences to allocate their portfolios effectively and efficiently. Expected return on investment also needs to be presented carefully so individual investors can evaluate the returns they will get. With the right allocation, investors can get the investment performance they want.

This research's limitation lies in the collection of data that is only done online due to the COVID-19 pandemic. Active social media users are dominated by young investors, so specific characteristics or categories dominate the data collected based on the respondent's profile. Next, this research only used a questionnaire to measure an individual's personality traits; it possible to be biased. For future research is suggested to use another model and measurement to minimize the biases. Future research can also use other types of 
investors, such as institutional investors, domestic investors, and foreign investors, to see each category's different behavior. Future research can also consider other independent variables to see their effect on investment decision-making and confirm the role of personality traits on investment performance.

\section{REFERENCES}

Abdin, S.Z. Ul, Farooq, O., Sultana, N. and Farooq, M. 2017. The impact of heuristics on investment decision and performance: Exploring multiple mediation mechanisms. Research in International Business and Finance.

Akhtar, F., Thyagaraj, K.S. and Das, N. 2018a. Perceived Investment Performance of Individual Investors is Related to the Big-Five and the General Factor of Personality (GPF). Global Business Review.

Akhtar, F., Thyagaraj, K.S. and Das, N. 2018b. The impact of social influence on the relationship between personality traits and perceived investment performance of individual investors: Evidence from Indian stock market. International Journal of Managerial Finance.

Barrick, M.R. and Mount, M.K. 1991. THE BIG FIVE PERSONALITY DIMENSIONS AND JOB PERFORMANCE: A META-ANALYSIS. Personnel Psychology.

Chaplin, J.P., 2012. Kamus Lengkap Psikologi. Jakarta: Rajawali Press.

Chen, T.H., Ho, R.J. and Liu, Y.W. 2019. Investor personality predicts investment performance? A statistics and machine learning model investigation. Computers in Human Behavior.

Costa, P.T. and McCrae, R.R. 1992. Revised NEO personality inventory (NEO-PI-R) and NEO five-factor inventory (NEO-FFI). Odessa FL Psychological Assessment Resources.

Dole, C. and Schroeder, R.G. 2001. The impact of various factors on the personality, job satisfaction and turnover intentions of professional accountants. Managerial Auditing Journal.

Durand, R.B., Newby, R. and Sanghani, J. 2008. An Intimate Portrait of the Individual Investor. Journal of Behavioral Finance.

Ellison, G. and Fudenberg, D. 1995. Word-of-mouth communication and social learning. Quarterly Journal of Economics.

Eugene, L.Y. and Yuan, S.T.D. 2012. Where's the money? The social behavior of investors in facebook's small world. In: Proceedings of the 2012 IEEE/ACM International Conference on Advances in Social Networks Analysis and Mining, ASONAM 2012.

Hair, J.F., Hult, G.T.M., Ringle, C.M. and Sarstedt, M. 2017. A Primer on Partial Least Squares Structural Equation Modeling (PLS-SEM). Second Edition. California: Sage.

Hair, J.F., Sarstedt, M., Hopkins, L. and Kuppelwieser, V.G. 2014. Partial least squares structural equation modeling (PLS-SEM): An emerging tool in business research. European Business Review. 


\section{Ninditya Nareswari \\ Citra Wanodya Rahmani \\ Nugroho Priyo Negoro}

Heinstrom, J. 2010. From Fear to Flow: Personality and information interaction. From Fear to Flow: Personality and Information Interaction.

Hirschey, M. Nofsinger, J. 2008. Investment Analysis and Behavior. New York: McGraw-Hill Irwin.

Ivković, Z. and Weisbenner, S. 2007. Information diffusion effects in individual investors' common stock purchases: Covet thy neighbors' investment choices. Review of Financial Studies.

Javed, H., Bagh, T. and Razzaq, S. 2017. Herding Effects, Over Confidence, Availability Bias and Representativeness as Behavioral Determinants of Perceived Investment Performance: An Empirical Evidence from Pakistan Stock Exchange (PSX). Journal of Global Economics.

Krohne, H. W., De Bruin, J. T., El-giamal, M., and Schmukle, S.C. 2000. The assessment of surgeryrelated coping: the coping with surgical stress scale. Psychology and Health, 15(1): 135-149.

Kubilay, B. and Bayrakdaroglu, A. 2016. An Empirical Research on Investor Biases in Financial Decision-Making, Financial Risk Tolerance and Financial Personality. International Journal of Financial Research.

Kustodian Sentral Efek Indonesia, 2020. Informasi Pasar. Jakarta.

Mahdzan, N.S., Mohd-Any, A.A. and Chan, M.K. 2017. The influence of financial literacy, risk aversion and expectations on retirement planning and portfolio allocation in Malaysia. Gadjah Mada International Journal of Business.

Martins, N. 2002. A model for managing trust. International Journal of Manpower.

Novianty, C. and Widyaastuti, M.C. 2019. Pengaruh Moderasi Kepribadian (Big Five Personality) Terhadap Hubungan Akuisisi Informasi dan Perilaku Perdagangan Saham Pada Investor Muda di Indonesia. Media Riset Bisnis and Manajemen, 19(2), p.82.

Patterson, F.M. and Daigler, R.T. 2014. The abnormal psychology of investment performance. Review of Financial Economics.

Phung, T.T.M. and Khuong, M.N. 2016. The Impact of the Big Five Traits and Mood on Investment Performance A Study of Individual Investors in Vietnam. SSRN Electronic Journal.

Sato, K., Miyazaki, K. and Mawaribuchi, J. 2011. Simple portfolio strategies utilizing inflation factor in Japanese equity market. In: Procedia Computer Science.

Sina, P.G. 2014. Tipe Kepribadian Dalam Personal Finance. Jibeka.

Tauni, M.Z., Rao, Z.U.R., Fang, H., Mirza, S.S., Memon, Z.A. and Jebran, K. 2017. Do investor's Big Five personality traits influence the association between information acquisition and stock trading behavior? China Finance Review International. 
Tauni, M.Z., Yousaf, S. and Ahsan, T. 2020. Investor-advisor Big Five personality similarity and stock trading performance. Journal of Business Research.

Tharp, V.K. 2008. The Definitive Guide to Position Sizing, 2nd edition. The Van Tharp Institute. 